The International Journal of Engineering and Science (IJES)

|| Volume || 6 || Issue || 3 || Pages || PP 58-63 || 2017 ||

ISSN (e): 2319 - 1813 ISSN (p): $2319-1805$

\title{
Use of Biogas Energy in Poultry Farming Heating
}

\author{
Ismail AL-Masalha ${ }^{1}$, Mutaz Elayyan ${ }^{2}$, Husam Aldean Bani Issa ${ }^{3}$ \\ ${ }_{1,2 \& 3}$ (Mechanical Engineering /Faculty of Engineering technology/ Al-Balqa' Applied University/ Amman \\ Jordan / Faculty of Engineering technology PO Box 15008 Amman, 11134, JordanPO Box 15008 Amman, \\ 11134,Jordan
}

Energy shortage is a global issue that is more severe in Jordan. One of the solutions to this problem in rural areas is the use of biogas energy either in heating applications or for electricity generation. The paper discusses the feasibility of using biogas produced from the fermentation of cow dung for the purpose of heating a standard poultry house, located around Queen Alia airport in the middle of Jordan. This work includes gathering information of a real poultry house and approximating some of its specifications; to calculate the required heating load of it throughout a whole year, which reached a maximum of $(62.39 \mathrm{~kW})$ in January. The next step is to find how much local traditional type of fuels, LPG and Diesel, are needed for the heating of this house. After that, through some calculations, the amount of biogas required and the amount of cow dung needed for its production is found. Finally, a financial analysis is applied to confirm the feasibility of this approach, which showed a payback period of about 15 months for the biogas system compared traditional heating fuel systems.

Date of Submission: 07 March 2017

Date of Accepted: 01 April 2017

Nomenclature
Symbol
$A$
$C p$
$E$
$Q$
$T_{i}$
$T_{o}$
$U$
$V$
$\rho$
$\rho_{m}$
$\rho_{C O 2}$
$V m$
$V_{C O 2}$
$V g$
$m_{m}$
$m_{C O 2}$
$m_{g}$
$r$
$H . V \cdot{ }_{L P G}$
$H . V \cdot{ }_{B i o g a s}$
$M_{g}$
$M_{L P G}$
$V$

\author{
Description \\ Area $\left(\mathrm{m}^{2}\right)$. \\ Air specific heat (kJ/kg.K). \\ Monthly energy saving $(k J)$. \\ Heat loss $(\mathrm{kW})$. \\ Inside temperature $\left({ }^{\circ} \mathrm{C}\right)$. \\ Minimum outside temperature $\left({ }^{\circ} \mathrm{C}\right)$. \\ Overall heat transfer coefficient $\left(\mathrm{W} / \mathrm{m}^{2} . K\right)$. \\ The ventilation required for the birds $\left(\mathrm{m}^{3} / \mathrm{s}\right)$. \\ Air density $\left(\mathrm{kg} / \mathrm{m}^{3}\right)$. \\ Methane density $\left(\mathrm{kg} / \mathrm{m}^{3}\right)$. \\ Carbon Dioxide density $\left(\mathrm{kg} / \mathrm{m}^{3}\right)$. \\ Methane volume produced from $1 \mathrm{~m}^{3}$ of dung $\left(\mathrm{m}^{3}\right)$. \\ CO2 volume produced from $1 \mathrm{~m}^{3}$ of dung $\left(\mathrm{m}^{3}\right)$. \\ Biogas volume produced from $1 \mathrm{~m}^{3}$ of dung $\left(\mathrm{m}^{3}\right)$. \\ Methane mass produced from $1 \mathrm{~m}^{3}$ of dung $(\mathrm{kg})$. \\ CO2 mass produced from $1 \mathrm{~m}^{3}$ of dung $(\mathrm{kg})$. \\ Biogas mass produced from $1 \mathrm{~m}^{3}$ of dung $(\mathrm{kg})$. \\ The ratio of LPG heating value to the biogas heating value. \\ $L P G$ heating value $(\mathrm{kJ} / \mathrm{kg})$. \\ Biogas heating value $(\mathrm{kJ} / \mathrm{kg})$. \\ The required mass of the biogas for the poultry heating $(\mathrm{kg})$. \\ The required mass of $L P G$ for the poultry heating $(\mathrm{kg})$. \\ The required volume of the dung $\left(\mathrm{m}^{3}\right)$.
}

\section{INTRODUCTION}

The rising consumption of fossil fuel sources, in addition to itsscarcity locally; urges to search for alternative energy sourcesto it. These alternatives, which are called renewable energies, have to be in multitude to fill the gap that may result from reducing the use of fossil fuels. Another factor that motivates the use of these sources is the pollution resulting from fossil fuels, beside solving the problem of depleting nature of fossil fuels.

Solar energy is the first renewable source that comesin mind. This type can be used easily for heating purposes or byusing photovoltaic cells converting itinto electricity. Almost every place Jordan is blessed with solarenergy, still there are many obstacles that hinders the use of solar energy in heating applications especially in rural areas. One of these obstacles is the intermittent nature of solar energy on daily basis. This forces the user 
to have some kind of heating storage system that adds to the cost of equipment's. Also, there are some periods in the winter where there is little or no solar power, this means an auxiliary heating unit working on fossil fuels is needed.

Another renewable energy source that canbe used in Jordan is geothermal energy.Although this type of energy is free once its infrastructure are constructed, still there are two problems encountering it in Jordan. The first problem is the applicability of this method to only few sites in Jordan as noticed in [1]. The second problem is the local legislations that prevent private use of Groundwater that is essential for geothermal heating process.

The third renewable energy source that can be used in Jordan is biogas.Many researchers have studied different aspects of biogas, like changing the components of cow dung as in [2]. Others have used some materials as a catalysts of the anaerobic digestions process as in [3] who used silica gel as the catalyst material for the cow dung. As mentioned above the researches topics about biogas production are very diverse, still not many researches discussed the feasibility ofsuch systems in Jordan especially in poultry farming. One of the few researches about biogas in Jordan was [4] who studied experimentally the operation of a biogas plant for water heating and electricity generation purposes. A more updated research in biogas production in Jordan is discussed by [5], where an estimation of the potential of biogas energy production is studied for the whole country. Another research applied in Jordan is [6], where they studied various factors on biogas digester experimentally, and the results were used for optimizing the digester performance using artificial neural network algorithm. Also,some commercial applications of biogas exists; such as electricity generation as in [7] where it produces about $9 \mathrm{MW}$ of electricity. In this work, the aim is to find if using biogas in heating purposes for agriculture applications, especially for poultry farms, is justified or not .

\section{Heat Load Calculations}

The target here is to find if the biogas energy will be enough to afford a standard poultry house with its requirement of heat. To do so, thermal loads of this house has to be calculated, then the generated loads from the biogas unithas to be calculated to verify if they are sufficient for the house loads. Finally, a fiscal study of the use of thermal energy is done to confirm if this use is justified or not. Before doing all these calculations some information has to be gathered aboutthe inside conditions of the houseand the location of the house beside the specifications of the house itself.

\section{Location data (Queen Alia airport):}

- $\quad$ Minimum outside temperature $\left(T_{0}\right)=3{ }^{\circ} \mathrm{C}$. [10]

- $\quad$ Ground temperature $=10.4^{\circ} \mathrm{C}$.[11]

- $\quad$ Wind speed $=3.3 \mathrm{~m} / \mathrm{s}$.[11]

Inside conditions of the poultry farm:

- The best range of inside temperature for adult chicken and is found in [8] to be $(18-24)^{\circ} \mathrm{C}$ for adult birds , so the inside temperature is chosen to be $22{ }^{\circ} \mathrm{C}$.

\section{Standard Poultry House specifications [8]:}

- The design of the poultry house was taken from an actual poultry house shown in figure (1), but with some specifications got from reference [9].

- $\quad$ Length $=64 \mathrm{~m}$.

- $\quad$ Width $=12 \mathrm{~m}$.

- $\quad$ Height $=3 \mathrm{~m}$.

- It has an air ventilation area around $6 \%$ of the house ground area.

- It has two (2 m x $2.5 \mathrm{~m})$ steel doors.

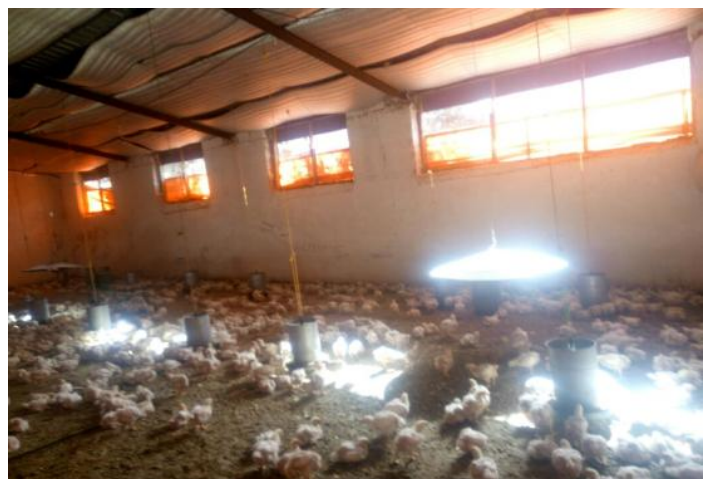

Figure 1: Conventional "pancake" brooders used for heating poultry house. 


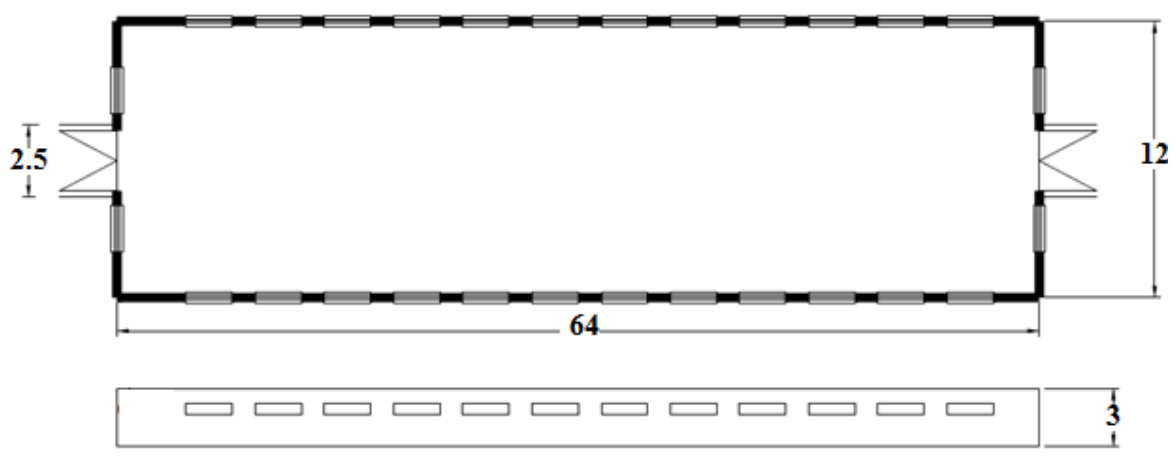

Figure 1: Graphical representation of a standard poultry house.

Calculations of the heating load for various components at the minimum outside temperature are shown below depending on the previous data.

\section{Heat load Calculations}

Traditional heat calculations are used for the various elements of heat losses. These elements are heat loss through walls,ceiling, ground doors and ventilation. Only the last element calculations are shown below because it differs from other types of heat loss and it contains some specific information to be presented.The results of these calculations are presented in table (2).

\section{Ventilation}

$Q_{\text {vent }}=m^{\prime} C_{p}\left(T_{i}-T_{0}\right)$

$m^{\prime}=V^{\prime} \rho$

The ventilation required $\left(V^{*}\right)$ for the birds is found using this equation:

$V^{\prime}=$ no of birds $\times$ average weig $\square t \times$ flow rate per $\mathrm{kg}$

To find the ventilation flow rate per $\mathrm{kg}$ of chicken meat data form table 9-1in reference [9] are used at a presumed operating temperature $\left(22^{\circ} \mathrm{C}\right)$. The result is found using interpolation to be $(0.851 \mathrm{cfm} / \mathrm{Ib}$ of body weight) which equals $\left(0.885 \times 10^{-4} \mathrm{~m}^{3} / \mathrm{s} / \mathrm{kg}\right)$.

Assuming a bird density of ( 9 birds $\left./ \mathrm{m}^{2}\right)$, the total number of birds will be:

no of birds $=9 \times 768=6912$ bird

The final assumption is that the average mass of these birds is $(2 \mathrm{~kg})$, so considering thisinformation:

$V^{*}=6912 \times 2 \times 0.885 \times 10^{-4}=1.217 \frac{\mathrm{m}^{\mathrm{a}}}{\mathrm{s}}$

At $\left(3{ }^{\circ} \mathrm{C}\right)$ the density of air and its specific heat are $\rho=1.29 \frac{\mathrm{kg}}{\mathrm{m}^{3}} ;$ and $C_{\mathrm{p}}=1.005 \frac{\mathrm{kJ}}{\mathrm{kg} \cdot \mathrm{K}}$. This meansthat:

$Q_{\text {vent }}=22.49 \mathrm{~kW}$

Table 1: Heat loads for various components in the poultry house

\begin{tabular}{|l|l|}
\hline Source of heat & Heat loss $(\mathrm{kW})$ \\
\hline Walls & 26.983 \\
\hline Doors & 0.378 \\
\hline Ceiling & 11.075 \\
\hline Ventilation & 22.49 \\
\hline Ground & 1.462 \\
\hline Total & 62.39 \\
\hline
\end{tabular}

\section{FEASIBILITY}

In this section the profits of using biogas energy in heating systems is studied. There are many heating methods in poultry houses that use different types of energy to create a suitable atmosphere for the chickens. Two of these methods depend traditionally on hot water coming from boilers. Here the boilers are to operated using three types of fuels which are Diesel, LPG and Biogas. Finally, an approximated feasibility study of this action is performed to assess the benefits of this use.

\section{Fuel consumption:}

There are two main fuels used in boilers for heating in general which are LPG and Diesel. To find the amount saved by the biogas energy which happens to suffice all the needs of the poultry house, a detailed calculation on 
monthly basis is done. The previous calculations represent the heating loads during the coldest outside temperature in January. The same calculations are done and shown in table 2 below, but with the difference that the outside temperature is taken as the average temperature.Also, for the summer months from May to September the minimum average temperature is considered to avoid day time which does not need heating.

Table 2: Heat Loss of all components throughout the year.

\begin{tabular}{|l|l|l|l|l|l|l|l|l|l|l|l|l|}
\hline & Jan & Feb & Mar & Apr & May & Jun & Jul & Aug & Sep & Oct & Nov & Dec \\
\hline $\begin{array}{l}\text { Source of } \\
\text { heat }\end{array}$ & $\begin{array}{l}\text { Heat } \\
\text { loss } \\
(\mathrm{kW})\end{array}$ & $\begin{array}{l}\text { Heat } \\
\text { loss } \\
(\mathrm{kW})\end{array}$ & $\begin{array}{l}\text { Heat } \\
\text { loss } \\
(\mathrm{kW})\end{array}$ & $\begin{array}{l}\text { Heat } \\
\text { loss } \\
(\mathrm{kW})\end{array}$ & $\begin{array}{l}\text { Heat } \\
\text { loss } \\
(\mathrm{kW})\end{array}$ & $\begin{array}{l}\text { Heat } \\
\text { loss } \\
(\mathrm{kW})\end{array}$ & $\begin{array}{l}\text { Heat } \\
\text { loss } \\
(\mathrm{kW})\end{array}$ & $\begin{array}{l}\text { Heat } \\
\text { loss } \\
(\mathrm{kW})\end{array}$ & $\begin{array}{l}\text { Heat } \\
\text { loss } \\
(\mathrm{kW})\end{array}$ & $\begin{array}{l}\text { Heat } \\
\text { loss } \\
(\mathrm{kW})\end{array}$ & $\begin{array}{l}\text { Heat } \\
\text { loss } \\
(\mathrm{kW})\end{array}$ & $\begin{array}{l}\text { Heat } \\
\text { loss } \\
(\mathrm{kW})\end{array}$ \\
\hline Walls & 26.983 & 23.128 & 17.346 & 7.709 & 6.746 & 4.818 & 3.855 & 2.891 & 4.818 & 1.927 & 13.492 & 23.128 \\
\hline Doors & 0.378 & 0.324 & 0.243 & 0.108 & 0.095 & 0.068 & 0.054 & 0.041 & 0.068 & 0.027 & 0.189 & 0.324 \\
\hline Ceiling & 11.075 & 9.492 & 7.119 & 3.164 & 2.769 & 1.978 & 1.582 & 1.187 & 1.978 & 0.791 & 5.537 & 9.492 \\
\hline Ventilation & 22.49 & 19.28 & 14.46 & 6.43 & 5.62 & 4.02 & 3.21 & 2.41 & 4.02 & 1.61 & 11.24 & 19.28 \\
\hline Ground & 1.462 & 1.253 & 0.940 & 0.418 & 0.366 & 0.261 & 0.209 & 0.157 & 0.261 & 0.104 & 0.731 & 1.253 \\
\hline Total & 62.39 & 53.47 & 40.11 & 17.82 & 15.60 & 11.14 & 8.91 & 6.68 & 11.14 & 4.46 & 31.19 & 53.47 \\
\hline
\end{tabular}

To calculate the energy saved for a certain month the following equation has to be used:

$E=$ no of days per mont $\square \times$ no of पours per day $\times$ Total पeating load $\times 3600$

For January the result will be:

$E=31 \times 24 \times 62.39 \times 3600=167105376 \mathrm{~kJ}$

The energy saved for all months of the year is presented in table 3 below, beside the amount of fuel saved as a result:

Table 3 : Monthly energy and fuel consumption for Diesel and LPG boilers.

\begin{tabular}{|l|l|l|l|l|l|l|l|l|l|l|l|l|}
\hline & Jan & Feb & Mar & Apr & May & Jun & Jul & Aug & Sep & Oct & Nov & Dec \\
\hline E(kJ)x 10 & 1.67 & 1.43 & 1.07 & 0.47 & 0.418 & 0.298 & 0.239 & 0.179 & 0.298 & 0.119 & 0.836 & 1.43 \\
\hline Diesel $(\mathrm{kg})$ & 4487.5 & 3846.4 & 2884.8 & 1282.1 & 1121.9 & 801.3 & 641.1 & 480.8 & 801.3 & 320.5 & 2243.7 & 3846.4 \\
\hline LPG (kg) & 4193.5 & 3594.4 & 2695.8 & 1198.1 & 1048.4 & 748.8 & 599.1 & 449.3 & 748.8 & 299.5 & 2096.8 & 3594.4 \\
\hline
\end{tabular}

Now the savings calculations for each fuel type are done based on the following equations which are found for January as an example:

cost of diesel $=m_{\text {Diesel }} \times$ Diesel $\frac{\text { price }}{\text { Diesel }}$ density
cost of diesel $=4487.5 \times 0.66 \times \frac{1}{0.845}=3505 \mathrm{JD}$

For LPG savings calculations this equation is used:

cost of $L P G=\frac{m_{L P G}}{m_{1} \text { cylinder }} \times$ cost of $t \square e$ cylinder
cost of $L P G=\frac{4193.5}{50} \times 45.96=3854.7 \mathrm{JD}$

Biogas production calculations:

$\rho_{m}=0.66 \frac{k g}{m^{2}}$

$\rho_{\mathrm{CO2}}=1.84 \frac{\mathrm{kg}}{\mathrm{m}^{\mathrm{a}}}$

According to [3] it is known that the biogas mainly is composed of around $65 \%$ methane by volume and about $35 \% \mathrm{CO}_{2}$, beside some negligible amounts of other gases. So , to describe the previous statement by equations then, knowing that $1 \mathrm{~m}^{3}$ of dung produces $10.667 \mathrm{~m}^{3}$ of biogas as can be deduced from[4], the following equations are needed for finding the gas mass produced in the process:

$$
\begin{aligned}
& V_{g}=V_{m}+V_{C O 2}=10.667 \\
& \text { but } V_{m}=0.65 V_{g} \\
& V_{m}=0.65(10.667)=6.929 \mathrm{~m}^{a} \\
& \text { Also, } \quad V_{C O 2}=0.35 \mathrm{~V}_{g} \\
& V_{\text {CO2 }}=0.35(10.667)=3.731 \mathrm{~m}^{\mathrm{a}}
\end{aligned}
$$

To find the total mass of biogas produced by $1 \mathrm{~m}^{3}$ of dung the below equation is used:

$m_{g}=m_{C O 2}+m_{m}$ 
$=\rho_{m} V_{m}+\rho_{C O 2} V_{C O 2}$

$=0.66 \times 6.929+1.84 \times 3.731$

$T$ पen, $\quad m_{g}=11.43 \mathrm{~kg} / \mathrm{m}^{\mathrm{a}}$ of dung

It is desired now to find the amount of consumption of the biogas in the same manner done with LPG ; knowing that the heating value of is approximated to be $(25000 \mathrm{~kJ} / \mathrm{kg})$. To do so, a new parameter is defined (r) which represents the ratio of LPG heating value to the biogas heating value:

$r=\frac{H \cdot V_{\text {:LPG }}}{H \cdot V_{\text {:Biogas }}}$
$r=\frac{45000}{25000}=1.8$

This parameter is used to approximate the required mass of the biogas without going in detailed calculations as before. For example, in Jan LPG consumption was $(4193.5 \mathrm{~kg}$ ) so if biogas is used then:

$M_{g}=r \times M_{L P G}$

$=1.8 \times 4193.5=7548.3 \mathrm{~kg}$

As a result, the required volume of the dung is:

$V=\frac{M_{g}}{m_{g}}$

$V=\frac{7548.3}{11.43}=656.031 \mathrm{~m}^{3}$

If the average cost of $1 \mathrm{~m}^{3}$ of dung is $(0.5 \mathrm{JD})$ that means the operational cost of using biogas method in the above example is (328 JD).

Table 4: Monthly savings by using Biogas energy.

\begin{tabular}{|l|l|l|l|l|l|l|l|l|l|l|l|l|}
\hline Savings & Jan & Feb & Mar & Apr & May & Jun & Jul & Aug & Sep & Oct & Nov & Dec \\
\hline Diesel (JD) & 3505.0 & 3004.3 & 2253.2 & 1001.4 & 876.2 & 625.9 & 500.7 & 375.5 & 625.9 & 250.4 & 1752.5 & 3004.3 \\
\hline LPG (JD) & 3854.7 & 3304.0 & 2478.0 & 1101.3 & 963.7 & 688.3 & 550.7 & 413.0 & 688.3 & 275.3 & 1927.3 & 3304.0 \\
\hline
\end{tabular}

Now to find if using biogas energy is lucrative it is desired to find the payback period of it. To do so, we firstly have to assume an annual interest rate (i) that equals 7\%. Also, the initial cost of each method has to be included where it is approximately 26000 JD for Biogas system and the other methods are about (4000 JD) as shown in table (5) and figure (2) below.

Table 5: Cash flow of heating methods for nine months period.

\begin{tabular}{|c|c|c|c|c|c|c|c|c|c|c|}
\hline & Initial cost & Jan & Feb & Mar & Apr & May & Jun & Jul & Aug & Sep \\
\hline Diesel & 4000.0 & 7528.3 & 10579.7 & 12899.0 & 13981.0 & 14944.7 & 15664.0 & 16262.6 & 16739.8 & 17470.3 \\
\hline LPG & 4000.0 & 7878.0 & 11231.7 & 13779.5 & 14966.9 & 16024.1 & 16812.6 & 17468.4 & 17990.6 & 18791.3 \\
\hline Biogas & 26000 & 26490.52 & 26937.24 & 27316.47 & 27580.91 & 27835.3 & 28067.84 & 28290.13 & 28502.09 & 28738.8 \\
\hline
\end{tabular}

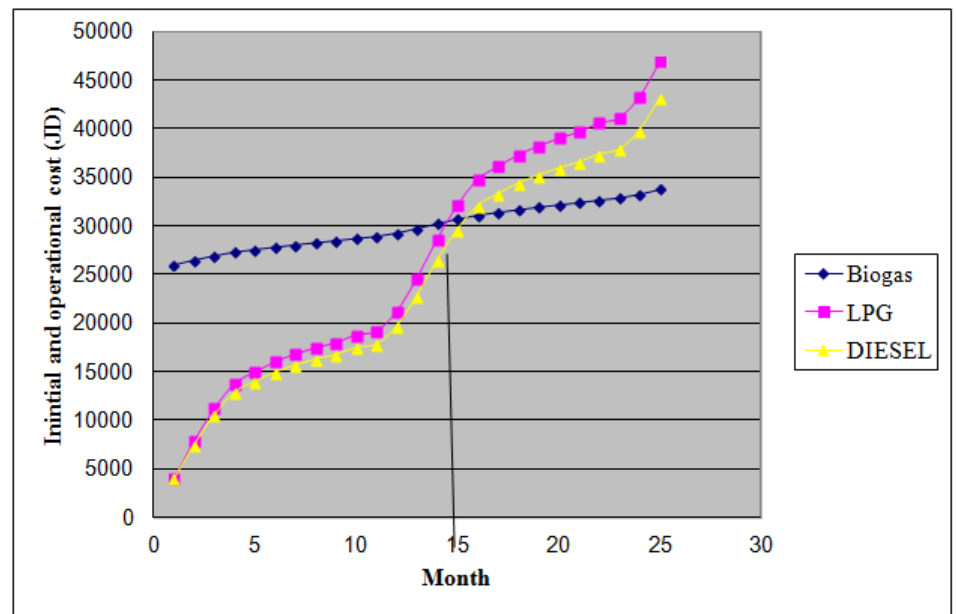

Figure 2: Comparison fo heating methods cash flows for twenty five months period.

\section{Conclusion}


Looking at the results where the payback period is just around 15 months, it can be said that using biogasheating systems is tempting to cut the costs of the high fuel consumptions. This means that farmers has to adopt thesesystems even though the initial cost may high at the beginning as this cost will be compensated easily by the savings of thesesystems.

\section{References}

[1] Ali Swarieh, 2000. GEOTHERMAL ENERGY RESOURCES IN JORDAN, COUNTRY UPDATE REPORT.Proceedings World Geothermal Congress 2000 (Kyushu - Tohoku, Japan, May 28 - June 10, 2000)

[2] Dipam Patowary, Helen West, Michèle Clarke, D.C. Baruah, 2016.Biogas Production from Surplus Plant Biomass Feedstock: SomeHighlights of Indo-UK R\&D Initiative.Procedia Environmental Sciences 35 ( 2016 ) 785 - 794.

[3] Bodius Salam, Sumana Biswas, Md Sanaul Rabbi, 2014. Biogas from Mesophilic Anaerobic Digestion of Cow Dung Using Silica Gel as Catalyst. 6th BSME International Conference on Thermal Engineering (ICTE 2014). Procedia Engineering 105 ( 2015 ) 652 657.

[4] R. Aburas, M. Hammad* \& I. Abu-Reesh, 1995. CONSTRUCTION AND OPERATION OF A DEMONSTRATION BIOGAS PLANT, PROBLEMS AND PROSPECTS.Bioresource Technology 53 (1995) 101-104.

[5] Zayed Al-Hamamre $\Uparrow$, Ali Al-Mater, Fawaz Sweis, Khaled Rawajfeh, 2014. Assessment of the status and outlook of biomass energy in Jordan. Energy Conversion and Management, 77, 183-192.

[6] H. Abu Qdais, K. Bani Hani, N. Shatnawi ,2010. Modeling and optimization of biogas production from a wastedigester using artificial neural network and genetic algorithm. Resources, Conservation and Recycling 54, 359-363

[7] Samra Electric Power Co. (SEPCO); http://sepco.com.jo/index.php?option=com_content\&view=article\&id=86\&Itemid=86.

[8] L. RUŽIĈIĆ, L. KOSTADINOVIĆ, K. GLIGOREVIĆ , M. OLJAĈA , 2013. APPLICATION OF GEOTHERMAL ENERGY IN AGRICULTURE.Agriculture \& Forestry, Vol. 59. Issue 2, 91-104

[9] DONALD D. B., WILLIAM D., JR. 2002. Commercial chicken meat and egg production 5th ed. SPRINGER SCIENCE+BUSINESS MEDIA, LLC.

ادهم سبع العيش, 2009 , كودة العزل الحر اري, عمان ,مجلس البناء الوطني الاردني + الجمعية العلمبة الملكية. [110]

[11] Al-Saad ,M. Hammad ,M., 2007. Heating and Air Conditioning for Residential Buildings 5th ed. Amman, Ajial press. 